\title{
PLASMA LEVELS OF ANTIDIURETIC HORMONE IN MAN DURING DIETHYL ETHER ANAESTHESIA AND SURGERY
}

\author{
Tsutomu Oyama, M.D., AND K. KImURA, M.D. ${ }^{*}$
}

ANAESTHESIA AND SURGERY produce oliguria in man. The antidiuresis is influenced by solute load, alterations in renal function, and a release of antidiuretic hormone $(A D H)$. There is evidence that narcotics, barbiturates, and general anaesthesia may provoke ADH secretion. ${ }^{1-3}$ Furthermore, an increase in plasma ADH with surgical stress has been shown in man., In recent years a new postoperative syndrome has been described in which hyponatraemia and renal salt loss, unrelated to either renal or adrenal disease, have been attributed to overexpansion of body fluids resulting from inappropriate secretion of $\mathrm{ADH}^{6-8}$ This syndrome has now been observed in a variety of malignant tumors, disorders involving the central nervous system, diseases of the lung, and idiopathic diseases. From these facts, anaesthesiologists should be aware of the role of $\mathrm{ADH}$ and the effects of anaesthesia and surgery on $\mathrm{ADH}$ secretion. However, $\mathrm{ADH}$ levels in human plasma during anaesthesia have not been reported previously. The present study was undertaken to investigate the effects of anaesthesia alone on the plasma ADH concentrations of patients and to compare the results with the effects of anaesthesia plus surgery. We attempted to explore the quantitative relationship between plasma ADH levels and the urine volume, urine osmolality, and blood osmolality, in order to evaluate the role of ADH in the antidiuresis produced by ether.

\section{METHOD}

Eleven patients ranging in age from 19 to 60 years were the subjects of the study. All patients underwent elective operations and no patient was included who had hepatic, renal, or endocrinologic disease. All patients underwent laparotomy, except two patients who underwent orthopaedic surgery (Table I). The eleven patients received pentobarbital (Nembutal) $2 \mathrm{mg} / \mathrm{kg}$ by mouth $13 / 2$ hours before operation, and meperidine (Demerol) $35 \mathrm{mg}$ with atropine $0.5 \mathrm{mg}$ intramuscularly one hour before operation. Anaesthesia was induced with nitrous oxide $2 \mathrm{~L} / \mathrm{min}$ and oxygen $2 \mathrm{~L} / \mathrm{min}$ in a semi-closed system; ether was administered by means of a copper kettle vaporizer. After obtaining the first blood sample at 30 minutes of ether anaesthesia, endotracheal intubation was done with the use of succinylcholine chloride. Afterwards the light anaesthesia group consisting of five patients was maintained at plane 1 of the third stage, and the moderate-deep group consisting of six patients was kept at plane $2-3$ of the third stage. These levels were judged by clinical signs, EEG, and arterial blood ether concentration determined with gas chromatographic analysis (30-92 $\mathrm{mg} / 100 \mathrm{ml}$ for the light group, and 102-

"Department of Anaesthesiology, Hirosaki University School of Medicine, Hirosaki, AomoriKen, Japan.

Canad. Anaesth. Soc. J., vol. 17, no. 5, September 1970 
TABLE I

Patients Studied and Operations Performed

\begin{tabular}{|c|c|c|c|c|c|}
\hline $\begin{array}{l}\text { Case } \\
\text { no. }\end{array}$ & Patients & Age & Sex & Surgery performed & $\begin{array}{l}\text { Depth of ether } \\
\text { anaesthesia }\end{array}$ \\
\hline 1 & Y.J. & 54 & $\mathrm{M}$ & \multirow{9}{*}{$\begin{array}{l}\text { gastrectomy } \\
\text { gastrectomy } \\
\text { hysterectomy } \\
\text { hysterectomy } \\
\text { prostatectomy } \\
\text { hysterectomy } \\
\text { gastrectomy } \\
\text { operative reposition } \\
\text { of clavicular fracture } \\
\text { para arterial } \\
\text { sympathectomy } \\
\text { sigmoidectomy } \\
\text { hysterectomy }\end{array}$} & light \\
\hline $\begin{array}{l}2 \\
3\end{array}$ & T.A. & $\begin{array}{l}56 \\
37\end{array}$ & $\stackrel{\mathrm{M}}{\mathrm{F}}$ & & $"$ \\
\hline 4 & A.G. & 57 & $\mathrm{~F}$ & & $"$ \\
\hline 5 & H.K. & 60 & $\mathrm{M}$ & & \\
\hline 6 & A.Y. & 37 & $\mathrm{~F}$ & & moderate \\
\hline $\begin{array}{l}7 \\
8\end{array}$ & $\begin{array}{l}\text { I.T. } \\
\text { Y.M. }\end{array}$ & $\begin{array}{l}58 \\
19\end{array}$ & $\stackrel{M}{M}$ & & deep \\
\hline 9 & M.F. & 30 & M & & deep \\
\hline & & & & & \\
\hline $\begin{array}{l}10 \\
11\end{array}$ & $\begin{array}{l}\text { K.M. } \\
\text { S.S. }\end{array}$ & $\begin{array}{l}30 \\
31\end{array}$ & $\frac{F}{F}$ & & moderate \\
\hline
\end{tabular}

$153 \mathrm{mg} / 100 \mathrm{ml}$ for the moderate-deep group). For the analysis of arterial concentration of ether, helium was used as a carrier gas, and polyethylene glycol (PEG $1500 \mathrm{~F}$ ) was employed as a column packing agent. The maximum coefficient of variation for the analysis was 1.3 per cent. Respiration was assisted intermittently throughout the procedure. Anaesthesia alone lasted for at least two hours in each case. $\mathrm{PO}_{2}, \mathrm{PCO}_{2}$, and $\mathrm{pH}$ were determined in arterial blood at $37^{\circ} \mathrm{C}$ by means of Astrup ultramicro equipment and a Severinghaus electrode.

Five blood samples were obtained from each patient: in the morning just before induction of anaesthesia, 30 minutes, one hour, and two hours after induction of anaesthesia before surgery, and ten minutes after the start of surgery. Thirty millilitre samples of venous blood were drawn, the serum was separated within 30 minutes, and the urine was collected through an indwelling catheter. All patients were fasted and no water was allowed for about ten hours prior to induction of anaesthesia. Five per cent fructose $1.4-2.0 \mathrm{ml} / \mathrm{min}$ was infused from $30 \mathrm{~min}$ before induction of anaesthesia until the end of operation. In addition, blood was transfused to replace the loss due to sampling and operation.

The ADH was extracted from plasma according to the method of Weinstein. ${ }^{9}$ The bioassay for this extracted plasma ADH was done according to Share's method. ${ }^{10}$ The plasma was mixed with three volumes of 5 per cent trichloroacetic acid ( $\mathrm{TCA}$ ) in a centrifuge tube. The solution was stirred by a magnetic bar. After centrifugation, the supernatant was decanted and filtered. The TCA precipitate was resuspended twice with 5 per cent TCA. The TCA filtrates were pooled and washed three times with equal volumes of ether, and the washed aqueous phase was adjusted to a $\mathrm{pH}$ of 4.0 with dilute $\mathrm{NH}_{4} \mathrm{OH}$ and passed through a column 1 $\mathrm{cm}$ in diameter and $2 \mathrm{~cm}$ high of $\mathrm{xE} 64$ resin to adsorb ADH. The column was washed with $10 \mathrm{ml}$ of distilled water, then $\mathrm{ADH}$ was eluted with 50 per cent acetic acid and dried in a flash evaporator at a temperature of $32^{\circ} \mathrm{C}$. The residue was dissolved in $1.2 \mathrm{ml}$ of an injection solution for bioassay that contained 0.03 per cent acetic acid, and 0.9 per cent normal saline. The sample was used for bioassay within one week from this point.

Following an overnight fast, male Wister strain rats (120-150 gm) were 
anaesthetized by 12 per cent ethanol $3 \mathrm{ml} / 100 \mathrm{~g}$ administered per mouth twice. A conductivity electrode was inserted surgically into the urinary bladder through a polyethylene tube, and was connected to a Wheatstone bridge. The electrical conductivity was recorded by a carrier amplifier. During bioassay the water containing 1.5 per cent ethanol, 1.67 per cent glucose, and 0.3 per cent $\mathrm{NaCl}$ at a rate of $0.12-0.15 \mathrm{ml} / \mathrm{min}$ was infused through the tail vein. Standards prepared from U.S.P. Posterior Pituitary Reference Standard 200 microunits per milliliter $(\mu \mathrm{U} / \mathrm{ml})$ were used. The dose-response relationship (response $=$ logarithm of the maximum conductance divided by the initial conductance) was linear between $10-80 \mu \mathrm{U}$ of vasopressin and its $\lambda=0.085$. When standard was added to freshly drawn blood immediately processed, $80.0 \pm 9.4$ ( $\pm=$ S.E.) was recovered by our method. Urine conductance was used as a response parameter and urinary output was observed for verification of antidiuretic activity. Serum osmolality was measured with an Advanced osmometer.

\section{Results}

The preoperative mean plasma ADH level was $2.9 \pm 1.3 \mu \mathrm{U} / \mathrm{ml}$ ( $\pm=$ s.E.). Since the normal plasma ADH level is considered to be $1.5-3.2 \mu \mathrm{U} / \mathrm{ml}$, the effects of preanaesthetic medication on plasma ADH activity were undetectable. The plasma ADH level was elevated remarkably to $16.9 \pm 3.5 \mu \mathrm{U} / \mathrm{ml}$, which was six times the preinduction level after 30 minutes of ether anaesthesia alone $(p<$ 0.01 ). After one hour of ether anaesthesia it gradually decreased to $9.1 \pm 1.6$ $\mu \mathrm{U} / \mathrm{ml}(p<0.05)$; two hours later it was $5.0 \pm 1.1 \mu \mathrm{U} / \mathrm{ml}$. However, these values were still higher than the control preinduction level. The plasma ADH level increased markedly again to $34.5 \pm 11.7 \mu \mathrm{U} / \mathrm{ml}(p<0.05)$ at ten minutes after the start of operation as illustrated in Table II and Figure 1.

It was noted that the increase in plasma ADH level was less prominent during

TABLE II

Plasma ADH Levels $(\mu \mathrm{U} / \mathrm{ml})$ during Ether- $\mathrm{N}_{2} \mathrm{O}$ Anaestuesia AND SURGERY

\begin{tabular}{cccccc}
\hline \hline & \multicolumn{5}{c}{ Time (min.) } \\
\cline { 2 - 6 } Cases & preinduction & anaes. $30^{\prime}$ & $60^{\prime}$ & $120^{\prime}$ & op. 10' \\
\hline 1 & 11.5 & 25.0 & 16.0 & 2.0 & 10.0 \\
2 & 1.0 & 10.5 & 11.5 & 2.7 & 25.0 \\
3 & 1.1 & 5.6 & 1.9 & 1.1 & 144.0 \\
4 & 6.3 & 46.0 & 17.4 & 14.6 & 25.0 \\
5 & 1.0 & 18.7 & 15.4 & 7.4 & 15.1 \\
6 & 1.1 & 23.3 & 9.6 & 7.1 & 4.1 \\
7 & 1.0 & 11.5 & 12.3 & 6.2 & 46.2 \\
8 & 3.0 & 8.6 & 5.8 & 7.0 & 13.2 \\
9 & 1.9 & 12.0 & 3.0 & 1.9 & 5.0 \\
10 & 1.8 & 22.1 & 4.5 & 2.3 & 64.3 \\
11 & 2.5 & 2.5 & 2.3 & 2.3 & 27.6 \\
Mean & 2.9 & 16.9 & 9.1 & 5.0 & 34.5 \\
s.E. & 0.93 & 3.50 & 1.68 & 1.16 & 11.67 \\
$p$ & & $<0.01^{*}$ & $<0.05^{*}$ & N.s.† & $<0.05^{*}$ \\
\hline
\end{tabular}

*Statistically significant compared with preinduction mean value. †Statistically not significant. 

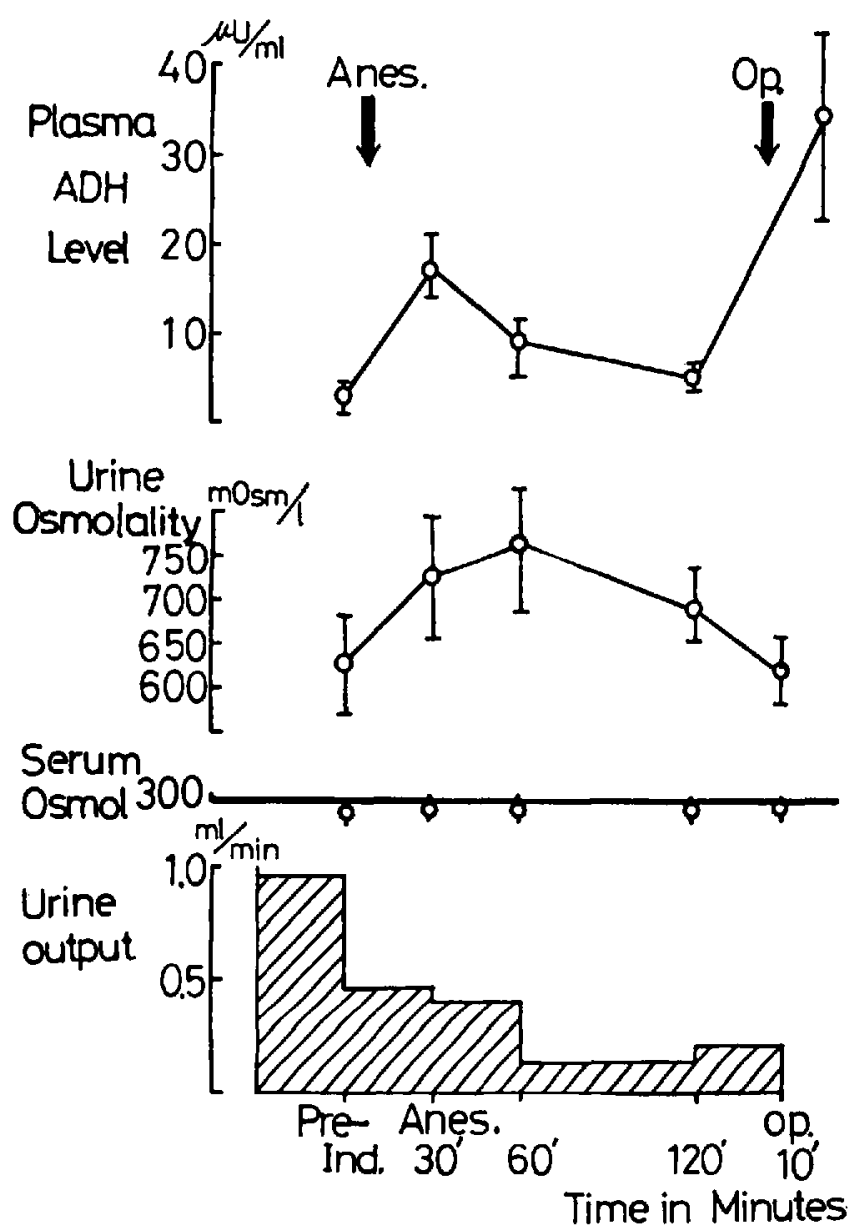

Ficure 1. Plasma ADH levels and changes in urine osmolality and urine output: mean values in 11 patients.

TABLE III

Changes in Urine Osmolaitity (mOsm $/ \mathrm{kg}$ ), Urine Output ( $\mathrm{ml} / \mathrm{min}$ ) and Serum Osmolality (mOsm $/ \mathrm{kg}$ ) DURING Ether- $\mathrm{N}_{2} \mathrm{O}$ Anaesthesia in Man (Mean Values of 11 Patients)

\begin{tabular}{llccccc}
\hline \hline & \multicolumn{5}{c}{ Time (min.) } \\
\cline { 2 - 7 } & & Preinduction & Anaes. 30' & $60^{\prime}$ & $120^{\prime}$ & op. 10' \\
\hline Urine osmolality & Mean & 642 & 723 & 756 & 692 & 612 \\
& S.E. & \pm 61 & \pm 74 & \pm 72 & \pm 41 & \pm 35 \\
Urine output & Mean & 0.98 & 0.45 & 0.44 & 0.16 & 0.19 \\
Serum osmolality & S.E. & \pm 0.22 & \pm 0.66 & \pm 0.17 & \pm 0.04 & \pm 0.05 \\
& Mean & 293 & 297 & 295 & 297 & 295 \\
& S.E. & \pm 7 & \pm 5 & \pm 4 & \pm 4 & \pm 5 \\
\hline
\end{tabular}

deep ether anaesthesia, as illustrated in Figure 2. In operations on the extremities or in orthopaedic procedures, elevation in the plasma ADH level was less prominent than in laparotomy. 


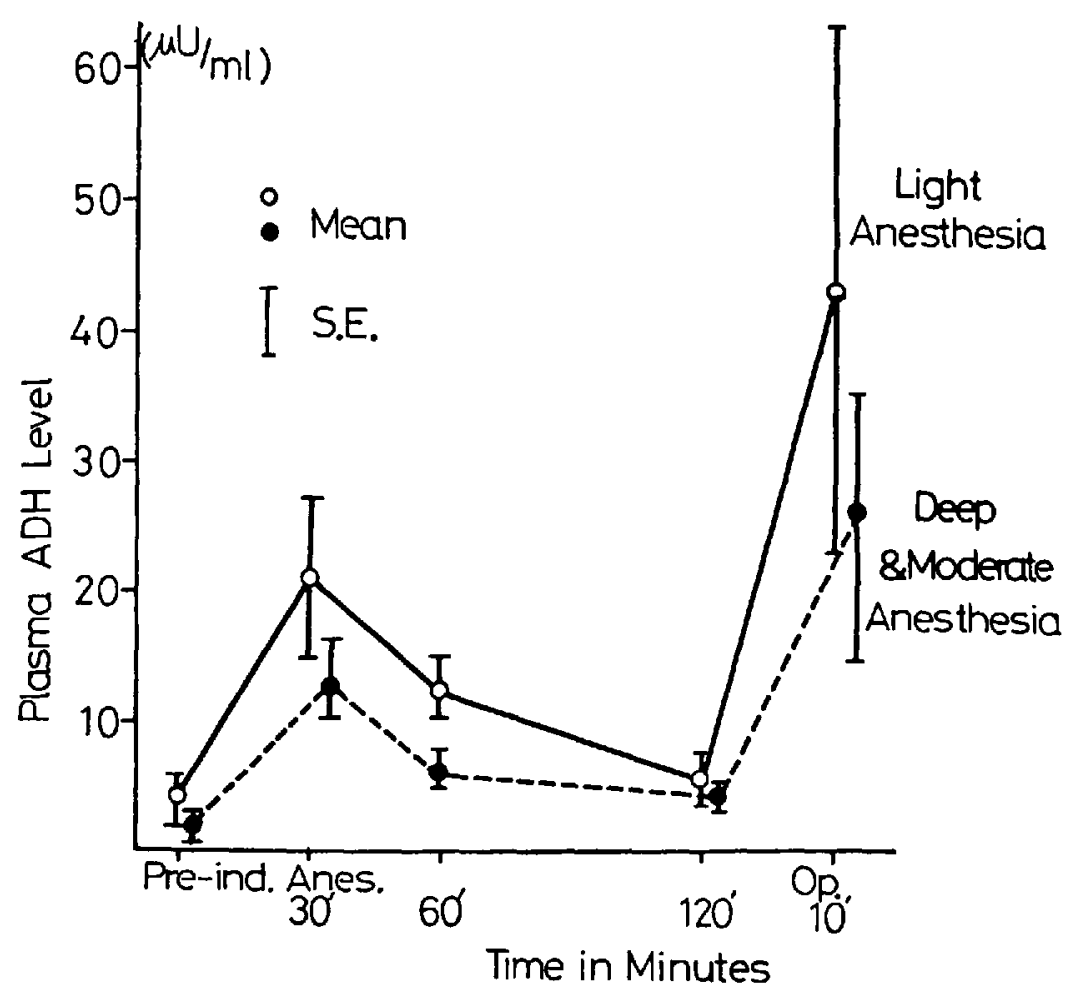

Figure 2. Plasma ADH levels during various depths of ether- $\mathrm{N}_{2} \mathrm{O}$ anaesthesia.

TABLE IV

Blood Gas Measurement during Ether-N ${ }_{2}$ O Anaesthesia in Man (Mean Values of 11 Patients)

\begin{tabular}{|c|c|c|c|c|c|}
\hline & \multicolumn{5}{|c|}{ Time (min.) } \\
\hline & Preinduction & Anaes. $30^{\prime}$ & $60^{\prime}$ & $120^{\prime}$ & op. $10^{\prime}$ \\
\hline $\begin{array}{l}\mathrm{pH} \\
\text { mean } \\
\text { S.E. }\end{array}$ & $\begin{array}{c}7.43 \\
\pm 0.007\end{array}$ & $\begin{array}{c}7.49 \\
\pm 0.017\end{array}$ & $\begin{array}{c}7.49 \\
\pm 0.016\end{array}$ & $\begin{array}{c}7.45 \\
\pm 0.021\end{array}$ & $\begin{array}{c}7.43 \\
\pm 0.017\end{array}$ \\
\hline $\begin{array}{l}\mathrm{P}_{\mathrm{CO}_{2}}(\mathrm{mmHg}) \\
\text { mean } \\
\text { S.E. }\end{array}$ & $\begin{array}{r}38.7 \\
1.3\end{array}$ & $\begin{array}{r}32.8 \\
1.5\end{array}$ & $\begin{array}{r}32.9 \\
1.7\end{array}$ & $\begin{array}{r}33.1 \\
1.7\end{array}$ & $\begin{array}{r}32.8 \\
1.6\end{array}$ \\
\hline $\begin{array}{l}\mathrm{PO}_{2}(\mathrm{mmHg}) \\
\text { mean } \\
\text { S.E. }\end{array}$ & $\begin{array}{r}83.4 \\
2.2\end{array}$ & $\begin{array}{r}209.5 \\
8.3\end{array}$ & $\begin{array}{r}217.2 \\
10.4\end{array}$ & $\begin{array}{r}207.5 \\
13.0\end{array}$ & $\begin{array}{r}191.0 \\
14.0\end{array}$ \\
\hline $\begin{array}{l}\text { B.E. } \\
\text { mean } \\
\text { S.E. }\end{array}$ & $\begin{array}{l}1.9 \\
0.43\end{array}$ & $\begin{array}{l}2.8 \\
1.26\end{array}$ & $\begin{array}{l}1.0 \\
1.08\end{array}$ & $\begin{array}{l}0.4 \\
1.09\end{array}$ & $\begin{array}{l}0.3 \\
0.81\end{array}$ \\
\hline $\begin{array}{l}\mathrm{HCO}_{3}(\mathrm{mEq} / \mathrm{U}) \\
\text { mean } \\
\text { s.E. }\end{array}$ & $\begin{array}{r}25.1 \\
0.8 \\
\end{array}$ & $\begin{array}{r}25.6 \\
1.4 \\
\end{array}$ & $\begin{array}{r}23.7 \\
1.2 \\
\end{array}$ & $\begin{array}{r}22.3 \\
1.0 \\
\end{array}$ & $\begin{array}{r}21.7 \\
1.0 \\
\end{array}$ \\
\hline
\end{tabular}

Urine volume was $0.98 \pm 0.22 \mathrm{ml} / \mathrm{min} 30$ minutes from the start of infusion of 5 per cent fructose until immediately before induction of anaesthesia. It decreased to $0.45 \pm 0.16 \mathrm{ml} / \mathrm{min}(p<0.01) 30$ minutes after induction; in the next 30 
minutes the value was $0.44 \pm 0.17 \mathrm{ml} / \mathrm{min}(p<0.001)$; from one to two hours after induction it was $0.16 \pm 0.04 \mathrm{ml} / \mathrm{min}(p<0.01)$. Urine volume decreased to $0.19 \pm 0.05 \mathrm{ml} / \mathrm{min}(p<0.01)$ ten minutes after the start of surgery. Urine osmolality reached the highest level from the control value of $642 \pm 61$ ( \pm S.E.) milliosmol $(\mathrm{mOsm}) / \mathrm{kg}$ to $756 \pm 72 \mathrm{mOsm} / \mathrm{kg}$ at one hour after the start of anaesthesia, followed by a gradual decrease to $612 \pm 35 \mathrm{mOsm} / \mathrm{kg}$ during the operation. Serum osmolality did not change significantly (Table III, Fig. 1). Measurement of arterial blood gases indicated neither anoxia nor metabolic acidosis existed during the course of the procedure (Table IV).

\section{Discussion}

Effects of preanaesthetic medication on plasma ADH activity were not stimulative in nature; that is, the average level of ADF in the blood after premedication was almost within the normal limit of $2.5 \mu \mathrm{U} / \mathrm{ml}$, except in two cases (no. 1 and no. 4). Patient no. 1 showed a high plasma ADH level $(11.5 \mu \mathrm{v} / \mathrm{ml})$ due to the dehydration which continued until immediately prior to induction, while patient no. 4 was nervous and the premedication was not adequate, therefore his ADH level was also high $(6.3 \mu \mathrm{U} / \mathrm{ml})$. Psychic stress ${ }^{11}$ and the administration of morphine, meperidine, and barbiturates ${ }^{12}$ have been reported to stimulate the release of ADH in animals, but another worker opposes this view. ${ }^{13}$

The plasma ADH level was remarkably increased to $16.9 \mu \mathrm{U} / \mathrm{ml}$, which was six times as much as the preinduction level after 30 minutes of ether anaesthesia alone. This was followed by gradual decrease almost to preinduction level two hours after the start of anaesthesia. The plasma $\mathrm{ADH}$ level rose again to 34.5 $\mu \mathrm{U} / \mathrm{ml}$ ten minutes after the start of operation. Decreases in urinary output and in urinary osmolality were observed. It is well known that general anaesthetic agents significantly diminish renal plasma flow, glomerular filtration, and water and electrolyte excretion in proportion to the depth of anaesthesia. Dudley et al. ${ }^{1}$ and Aprahamian et al., ${ }^{2}$ who observed the increase in urinary osmolality, suggested that ether and cyclopropane might increase $\mathrm{ADH}$ secretion in man. However, no direct measurement of plasma ADH concentrations was made.

The primary physiological functions of posterior pituitary ADH (vasopressin) are the regulation of the osmotic pressure of extracellular fluid and the regulation of blood volume. It stimulates tubular reabsorption of free water, concentrating urine, and decreases urine volume; it also constricts blood vessels. The plasma $\mathrm{ADH}$ level is influenced by many factors such as secretion of $\mathrm{ADH}$ from the posterior pituitary, metabolism in the liver and kidneys, and renal excretion.

There are many factors which are considered to affect the ADH secretion from the pituitary glands and thereby control the tonicity and volume of the body fluids. ${ }^{16}$ They include stimulation of osmoreceptors located in the supraoptic and paraventricular nuclei of the hypothalamus, which are sensitive to changes in the effective solute concentration of the extracellular fluids, stimulation of baroreceptors in the cartoid sinus or aortic arch by arterial hypotension, and stimulation of left atrial volume receptors by decreases in blood volume.

The effect of ether anaesthesia on ADH secretion is speculated to be due to the 
direct stimulation or the decrease in blood volume for the following reasons. The increase in blood osmolality during ether anaesthesia was too little to be attributable to the increase in blood $\mathrm{ADH}$, although Aubry and his co-workers ${ }^{14}$ reported that an increase of 2 per cent in the osmotic pressure of the plasma is sufficient to inhibit a water diuresis in man. Decrease in blood volume during ether anaesthesia in man ( 9.6 per cent, 20 minutes; 4.9 per cent, 80 minutes) was reported by Price et al. ${ }^{15}$ According to Share, ${ }^{10}$ when extracellular fluid volume was reduced by 15 per cent (a 9 per cent reduction in blood volume), there was a sixfold increase in the blood level of vasopressin, although mean arterial blood pressure was unchanged. Therefore we cannot neglect a factor of reduction in blood volume during ether anaesthesia.

In our study there was a tendency to more reduction in arterial blood pressure in the moderate-deep anaesthesia group than in the lightly anaesthetized group. Nonetheless, it was noted that the increase in plasma ADH level was less prominent during deep ether anaesthesia; this observation differs from the views of Backman $^{17}$ and Aprahamian. ${ }^{2}$ The anaesthetic depth, changes in body temperature, or changes in blood pressure might account in part for the variations in plasma $\mathrm{ADH}$ levels observed. However, these factors were kept as constant as possible during the procedure. It is difficult to postulate a clear-cut mechanism of elevation of the plasma ADH level and its relation to biotransformation and excretion during ether anaesthesia in the present study. However, our data are interpreted as indicating that the raised ADH secretion during anaesthesia and surgery contribute in part to the effect of decreased urine formation. Furthermore, it was quite apparent that plasma ADH changed rapidly during anaesthesia and surgery.

Our observation of a transient and marked elevation in the plasma ADH level associated with peritoneal incision or visceral traction agrees with the finding of Moran and co-workers. ${ }^{4,5}$ According to them a gradual decline of ADH to normal values after closing of the skin incision is usually observed by the fifth postoperative day, following major surgical procedures.

\section{SUMMary AND ConClusions}

The present study was undertaken to determine the plasma antidiuretic hormone (ADH) during ether anaesthesia and surgery by utilizing a bioassay technique. The measurements of osmolality in serum and urine, and of urine output, were performed simultaneously. The present study clearly demonstrated a remarkable participation of $\mathrm{ADH}$ in decreased urine output and in elevation of urinary concentration in 11 patients. Plasma ADH level was increased markedly from 2.9 \pm 0.93 to $16.9 \pm 3.5 \mu \mathrm{U} / \mathrm{ml}$, which was a sixfold elevation from preinduction concentration after 30 minutes of ether anaesthesia alone. This was followed by gradual decline almost to preinduction levels in two hours after the start of anaesthesia but before the operation. Plasma ADH levels increased again to 34.5 $\pm 11.7 \mu \mathrm{v} / \mathrm{ml}$ ten minutes after the start of operation. A decrease in urinary output and an increase in urinary osmolality were also observed. The increase in plasma ADH level was less marked during deep ether anaesthesia. In operations on the extremities or in orthopedic procedures, elevation in the plasma ADH level 
was less prominent than in laparotomy. Our study clearly indicates that the raised ADH secretion during anaesthesia and surgery contribute in part to the decreased urine formation.

\section{RÉSUMÉ}

Nous avons entrepris cette étude pour déterminer, au cours de l'anesthésie à l'éther et de la chirurgie, les taux d'hormone antidiurétique plasmatique (ADH) en employant une technique par dosage biologique. La présente étude a démontré clairement, chez onze malades, une participation remarquable de l'ADH dans la diminution du débit et dans l'augmentation de la concentration urinaire. Le taux plasmatique d'ADH s'est accru de façon marquée, soit : de $2.9 \pm 0.93$ à $16.9 \pm 3.5$ $\mu \mathrm{U} / \mathrm{ml}$, après 30 minutes d'anesthésie à l'éther; cela est un taux six fois plus élevé que le taux existant avant d'induction. Puis, ce taux a diminué graduellement pour atteindre, en deux heures après le début de l'anesthésie et avant la chirurgie, presque le taux existant avant l'induction. Dix minutes après le début de la chirurgie, le taux d'ADH plasmatique s'est accru de nouveau pour atteindre $34.5 \pm$ $11.7 \mu \mathrm{U} / \mathrm{ml}$. Nous avons observé également une diminution du débit et une augmentation de l'osmolalité urinaire. Au cours de l'anesthésie profonde à l'éther, l'augmentation du taux d'ADH plasmatique a été moins prononcée. Au cours des opérations orthopédiques ou des opérations effectuées sur les extrémités, l'élévation du taux d'ADH plasmatique était moins évident qu'a cours d'une laparotomie. Notre étude démontre, de façon claire, que l'augmentation de la secrétion d'ADH plasmatique survenant au cours de l'anesthésie et de la chirurgie est particulièrement responsable de la diminution du débit urinaire.

\section{REFERENCES}

1. Dudley, H. F.; Bolinc, E. A.; LeQuesne, L. P.; \& Moore, F. D. Effect of Anesthesia, Surgery and Posterior Pituitary Antidiuretic Hormone on Water Metabolism in Man. Ann. Surg. 140: 354 (1954).

2. Aprahamian, H. A.; Vanderveen, J. L.; Bunker, J. P.; Murphy, A. J.; \& Crawford, J. D. The Influence of General Anesthetics on Water and Solute Excretion in Man. Ann. Surg. 150: 122 (1959).

3. Pappen, S. \& Papper, E. M. The Effects of Preanesthetic, Anesthetic, and Postoperative Drugs on Renal Function. Clin. Pharmacol. \& Therap. 5: 205 (1964).

4. Moran, W. H.; Miltenberger, F. W.; Shuayb, W. A.; \& Zimmermann, B. The Relationship of Antidiuretic Hormone Secretion to Surgical Stress. Surgery. 56 : 99 (1964).

5. Ukai, M.; Moran, W. H., JR.; \& ZmmmenmanN, B. The Role of Visceral Afferent Pathways on Vasopressin Secretion and Urinary Excretory Patterns during Surgical Stress. Ann. Surg. 168: 16 (1968).

6. Schwartz, W. B.; BennetT, W.; Curelop, S.; \& Barter, F. C. A Syndrome of Renal Sodium Loss and Hyponatremia Probably Resulting from Inappropriate Secretion of Antidiuretic Hormone. Am. J. Med. 23: 529 (1957).

7. Deutsch, S.; Goldberg, M.; \& DrIPPS, R. D. Postoperative Hyponatremia with the Inappropriate Release of Antidiuretic Hormone. Anesthesiology. 27: 250 (1966).

8. Barter, F. C. \& Schwantz, W. B. The Syndrome of Inappropriate Secretion of Antidiuretic Hormone. Am. J. Med. 42: 790 (1967).

9. WeInstein, H. R.; Berne, R. M.; \& Sachs, H. Vasopressin in Blood: Effect of Haemorrhage. Endocrinology. 66: 712 (1960).

10. Share, L. Acute Reduction in Extra Cellular Fluid Volume and the Concentration of Antidiuretic Hormone in Blood. Endocrinology. 69: 925 (1961).

11. O'Conner, W. J. \& Verney, E. B. The Effect of Increased Activity of the Sympathetic 
System in the Inhibition of Water Diuresis by Emotional Stress. Quart. J. Exper. Physiol. 33: 77 (1945).

12. Winter, C. A.; Gaffney, C. E.; \& Flataker, L. The Effect of N-Allylnormophine upon the Antidiuretic Action of Morphine. J. Pharmacol. \& Exper. Therap. 111: 360 (1954).

13. Papper, S.; Belsky, J. L.; Blejfer, K. H.; Saxon, L.; \& SMith, W. P. Effect of Meperidine and Secobarbital upon Renal Excretion of Water and Solute in Man. J. Lab. \& Clin. Med. 56: 727 (1960).

14. Aubri, R. H.; NANeIN, H. R.; Moses, A. M.; \& Streeten, D. H. P. Measurement of the Osmotic Threshold for Vasopressin Release in Human Subjects, and Its Modification by Cortisol. J. Clin. Endocrinol. 25: 1481 (1965).

15. Price, H. L.; Helmruch, M.; \& Conner, E. H. A Relation between Hemodynamic and Plasma Volume Alterations during General Anesthesia in Man. J. Clin. Invest. 35: 125 (1956).

16. Share, L. Vasopressin: Its Bioassay and the Physiological Control of Its Release. Am. J. Med. 42: 701 (1967).

17. BACKMAN, L. The Antidiuretic Effects of Anesthetic Agents. Anesthesiology. 16: 939 (1955). 